\title{
Mutagenicity induced by the hydroalcoholic extract of the medicinal plant Plathymenia reticulata Benth
}

Della Torre A (1), Albuquerque LBL (1), Farrapo NM (1), Oshima-Franco Y (1), Santos MG (2), Tavares RVS (1), Rodas ACD (3), Dal Belo CA (4), Cardoso CRP (5), Varanda EA (5), Groppo FC (6), Lopes PS (7)

(1) University of Sorocaba, UNISO, Sorocaba, São Paulo State, Brazil; (2) Federal University of Tocantins, UFT, Porto Nacional, Tocantins State, Brazil; (3) Nuclear and Energy Research Institute, IPEN, São Paulo, São Paulo State, Brazil; (4) Federal University of Pampa, UNIPAMPA, São Gabriel, Rio Grande do Sul State, Brazil; (5) São Paulo State University (UNESP - Univ Estadual Paulista), Araraquara, São Paulo State, Brazil, Brazil; (6) Piracicaba Dental School, University of Campinas, UNICAMP, Piracicaba, São Paulo State, Brazil; (7) Federal University of São Paulo, UNIFESP, Diadema, São Paulo State, Brazil.

\begin{abstract}
Plathymenia reticulata Benth has an anti-inflammatory effect and is capable of neutralizing the neuromuscular blockade induced by Bothrops jararacussu or Crotalus durissus terrificus venoms, probably by precipitating venom proteins (an effect caused by plant tannins). The present study aimed to evaluate the mutagenic activity of $P$. reticulata by using the Salmonella mutagenicity assay (Ames test) and the micronucleus test in CHO-K1 cells. P. reticulata extract concentrations of 2.84, 5.68, 11.37, and $19.90 \mathrm{mg} /$ plate were assayed by the Ames test using TA97a, TA98, TA100 and TA102 bacterial strains, with (+S9) and without (-S9) metabolic activation. Concentrations of $5,1.6$ and $0.5 \mu \mathrm{g} / \mathrm{mL}$ of $P$. reticulata extract were used for the micronucleus test. P. reticulata extract was mutagenic to TA98 (-S9) and showed signs of mutagenic activity in TA97a and TA102 (both -S9) strains. Micronucleus test CBPI values showed that the endogenous metabolic system increased the number of viable cells when compared to the non-activated samples and the micronucleus frequency increased when the cells were treated in the absence of S9. We concluded that P. reticulata extract may present direct mutagenic properties.
\end{abstract}

Key words: Ames test, micronucleus test, mutagenicity, plant extract, Plathymenia reticulata.

\section{INTRODUCTION}

The Brazilian savanna, known as "cerrado", is one of the most biologically diverse areas in Brazil. Plathymenia reticulata Benth, popularly known as "vinhático" (wine-like), belongs to the Leguminosae family, which is a source of high quality wood. It may also be useful in restoring deforested areas, mainly in the savanna region, making it an economically important tropical species (1).

$P$. reticulata has been used to treat inflammatory processes (throat) and diseases (diarrhea, dysenteries), in folk medicine (2). According to Pott and Pott (3), its bark is also used to make a medicinal bath for various illnesses (hemorrhage and insect bites). $P$. reticulata extract showed in vitro antimicrobial activity against Streptococcus mutans and Staphylococcus sp. (4). Leal et al. (5) reported the isolation and structural elucidation of two novel cassane diterpenes and the isolation of three previously reported compounds: plathyterpol, vinhaticyl acetate and methyl vinhaticoate (6, $7)$. The recently described antiophidian property of $P$. reticulata hydroalcoholic extract obtained from its bark showed that tannins from this plant were able to precipitate proteins of both Crotalus and Bothrops venoms (8).

In the present study, the mutagenicity of $P$. reticulata bark was investigated by using Salmonella (Ames test) and CHO-K1 (Chinese hamster ovary) micronucleus assays, in order to observe its safety. 


\section{MATERIALS AND METHODS}

\section{Vegetal Material and Extraction Procedure}

Samples of $P$. reticulata Benth bark were collected from the Miracema city herbarium (Miracema, Tocantins, Brazil) in October 2006. The specimens were deposited (protocols NRHTO 3327) at the herbarium of the Federal University of Tocantins. The bark was dried at $40^{\circ} \mathrm{C}$ in an incubator with forced air circulation apparatus for 48 hours. The material was ground in a mill (MA $340^{\circ}$, Marconi, Brazil), macerated for seven days (1276.32 g) in 70\% ethanol (14.5 liters) and the suspension was protected from light and percolated at 20 drops/minute, resulting in a $20 \%(\mathrm{w} / \mathrm{v})$ hydroalcoholic extract. The obtained extract was then concentrated in a rotary evaporator (TE- $210^{\circ}$, Tecnal, Brazil) and lyophilized (Multi-Tasking Freeze Drying S, SNL216V-115, Thermo Fisher Scientific, USA).

\section{Salmonella Mutagenicity Assay}

Mutagenicity was evaluated by the Salmonella mutagenicity assay via the Salmonella typhimurium strains TA97a, TA98, TA100, and TA102 (kindly provided by Dr. B. Ames, University of California, Berkeley, CA, USA), pre-incubated for 20 to 30 minutes with the test substance, with $(+)$ or without $(-)$ metabolic activation (S9) (9). The S9 mix was freshly prepared before each test using a lyophilized Aroclor-1254-induced rat liver fraction (Moltox, Molecular Toxicology Inc, USA). The selected concentrations of the extracts to be used were dissolved in dimethylsulfoxide (DMSO - SigmaAldrich, USA). These concentrations were chosen based on the bacterial toxicity assay in a preliminary test. In all subsequent assays, the upper limit of the dose range tested was either the highest non-toxic dose or the lowest toxic dose determined in the preliminary assay $(2.84,5.68$, 11.37 , and $19.90 \mathrm{mg}$ /plate).

Toxicity was apparent either as a reduction in the number of His+ revertants or as an alteration in the auxotrophic background lawn. The various concentrations of samples were added to $500 \mu \mathrm{L}$ of buffer ( $\mathrm{pH} 7.4$ ) or $500 \mu \mathrm{L}$ of $\mathrm{S} 9$ mixture (4\%) and $100 \mu \mathrm{L}$ of bacterial culture and then incubated at $37^{\circ} \mathrm{C}$ for 20 to 30 minutes. After this time, $2 \mathrm{~mL}$ of top agar was added to the mixture and poured onto a plate containing minimal agar. The plates were incubated at $37^{\circ} \mathrm{C}$ for 48 hours and the His+ revertant colonies were manually counted.

All experiments were performed in triplicate. The standard mutagens used as positive controls in -S9 experiments were 4-nitro-ophenylenediamine $(10 \mu \mathrm{g} /$ plate $)$ for TA98 and TA97a, sodium azide $(1.25 \mu \mathrm{g} /$ plate $)$ for TA100 and mitomycin $(0.5 \mu \mathrm{g} /$ plate $)$ for TA102. In $+S 9$ tests, 2 -anthramine $(0.125 \mu \mathrm{g} /$ plate $)$ was used for all strains. DMSO served as the negative (solvent) control.

The statistical analysis was performed with the Salanal computer program, adopting the Bernstein et al. model (10). The data (revertants/ plate) were assessed by analysis of variance (ANOVA), followed by linear regression. The mutagenic index (MI), defined as the average number of revertants per plate divided by the average number of revertants per plate in the negative (solvent) control, was calculated for each dose. A sample was considered positive when MI was greater than or equal to 2 for at least one of the tested doses and if it had a reproducible doseresponse curve (11).

\section{Cell Line and Culture Conditions}

Chinese hamster ovary cells ( $\mathrm{CHO}-\mathrm{K} 1$ lineage, ATCC number CCL-61) were maintained at $37^{\circ} \mathrm{C}$ in 5\% $\mathrm{CO}_{2}$ and $97 \%$ humidity in RPMI 1640 tissue culture medium (Gibco, USA), supplemented with $10 \%(\mathrm{v} / \mathrm{v})$ fetal bovine serum (FBS - Gibco), $1 \%(\mathrm{v} / \mathrm{v})$ L-glutamine (L-Glu - Gibco), $1 \%$ (v/v) penicillin-streptomycin (PS - Gibco) and $0.1 \%(\mathrm{v} / \mathrm{v})$ amphotericin B (Gibco) (12). For subculturing and experiments, the cells were harvested using $0.05 \%(\mathrm{w} / \mathrm{v})$ trypsin and $0.02 \%$ (w/v) ethylene diamine tetracetic acid (EDTA) in a saline phosphate-buffered solution, $\mathrm{pH}$ 7.4. Each trypsinization was recorded as one passage. The test was performed at the third passage.

\section{In Vitro Micronucleus Test}

This experiment was carried out according to the procedure OECD 487 from the Guideline for the Testing of Chemicals (13). The test was performed in six-well plates in the presence $(+)$ or absence (-) of the $S 9$ metabolic activation system, and the cultures were in duplicate. The procedure was carried out in steps, as follows:

\section{Time and conditions of cell culture}

$\mathrm{CHO}-\mathrm{K} 1$ cells were seeded at a concentration 
of $3 \times 10^{4}$ cells per well and incubated for 24 hours at $37^{\circ} \mathrm{C}$ in a humidified $5 \% \mathrm{CO}_{2}$ atmosphere.

\section{Removal of the medium to addition of treatments}

The culture media were removed from the plates and the cells were treated either with the control or the hydroalcoholic extract at $0.5,1.6$ or $5 \mu \mathrm{g} / \mathrm{mL}$ concentrations, which were defined after the cytotoxicity evaluations (data not shown). The -S9 assay was carried out on plates containing the extract at three different concentrations, using 0.5 $\mu \mathrm{g} / \mathrm{mL}$ mitomycin $\mathrm{C}$ and $0.08 \mu \mathrm{g} / \mathrm{mL}$ colchicine as a positive control. To carry out the $+\mathrm{S} 9$ assay, approximately $75 \mu \mathrm{L}$ of the $\mathrm{S} 9$ metabolic activation mixture was added to the plates that already contained $5 \mu \mathrm{g} / \mathrm{mL}$ cyclophosphamide and $3 \mu \mathrm{g} / \mathrm{mL}$ benzopyrene as positive controls and the extract at the different concentrations as previously described.

\section{Incubation for four hours}

\section{Addition of cytochalasin B with medium}

- On the -S9 plates, cytochalasin B solution was added to the wells at $3 \mu \mathrm{g} / \mathrm{mL}$ final concentration.

- On the +S9 plates, first the media were removed by aspiration, and the cells were rinsed with a phosphate buffer solution $(\mathrm{pH}$ 7.4) and replenished with complete medium containing $3 \mu \mathrm{g} / \mathrm{mL}$ cytochalasin B.

\section{Twenty more hours of culturing}

Both treatments $(-\mathrm{S} 9$ and $+\mathrm{S} 9)$ returned to the incubator for an additional 20-hour incubation period. Afterward, the cultures were processed using subculture procedures to prepare slides for analysis (as described below).

\section{Preparation and analysis of slides}

The cell suspension was washed with $5 \mathrm{~mL}$ of $0.9 \%(\mathrm{w} / \mathrm{v})$ saline solution, and after five minutes the cells were fixed by adding $5 \mathrm{~mL}$ of methanol/acetic acid (3:1 v/v) for five minutes. After fixation, the cell suspension was centrifuged at $1,500 \mathrm{rpm}$ for five minutes. The re-suspended cells were dropped on wet-clean glass slides inside a thermostated bath, set at $65^{\circ} \mathrm{C}$, for three minutes and left to air dry.

The slides were stained for 15 minutes with Giemsa (Gibco) 5\% in Sörensen buffer, rinsed with distilled water, coded and analyzed with an optical microscope (Nikon, Model Alphaphot-2 YS2-H, USA), at 400x magnification. The mononucleate, binucleate and multinucleate cells were counted by using the cytokinesisblock proliferation index (CBPI) and replicative index (RI) in agreement with the equations for cytotoxicity assessment, which are described in the OECD 487 guideline (13).

For statistical analysis, the binomial proportion confidence interval (Poisson model) was adopted and the variation was assessed by using a one-way analysis of variance (ANOVA) between negative controls (samples with and without S9 mix) and positive controls (+ and -S9 mix) (14).

\section{RESULTS AND DISCUSSION}

Brazil has a very large number of native plant species that are considered medicinal (15-17). However, many of them have not yet been studied for medicinal purposes. $P$. reticulata Benth, a tree that grows in dry areas of central Brazil, has potential medicinal, forestry, ink and ornamental applications (18). Caramori et al. (19) analyzed and quantified the presence of compounds such as lectins and trypsin-like inhibitors, polyphenols and tannins, and the enzymatic activity of peroxidases and proteases from the seeds of $P$. reticulata.

The safe use of plants is commonly assumed in traditional medicine. This safety is based on their long usage in the treatment of diseases according to knowledge accumulated over centuries. However, recent scientific data have shown that many plants used as food or in traditional medicine are potentially toxic, mutagenic or carcinogenic (20). In addition, epidemiological data support the idea that tannins, among other vegetal antioxidant agents, have the ability to modulate certain cell signaling pathways and gene expression $(21,22)$. The present study observed the mutagenic potential of $P$. reticulata bark in order to ensure its safety for human use.

Of the approximately $1276.32 \mathrm{~g}$ of $P$. reticulata Benth dried bark processed, $1256.37 \mathrm{~g}$ of the powdered drug was obtained, resulting in $98.43 \%$ (w/w) purity. After percolation of the powdered drug, the 16 liters of hydroalcoholic extract obtained was concentrated down to $780 \mathrm{~mL}$ and lyophilized, thus producing $327.73 \mathrm{~g}$ that was properly stored until usage. 
Table 1 shows the mutagenic activity of hydroalcoholic extract from $P$. reticulata bark using $S$. typhimurium strains. These strains have a defect in one of the genes involved in histidine biosynthesis. The defect renders the cell dependent (auxotrophic) on exogenous histidine. Unless the cell experiences a mutation that causes reversion of the dysfunctional gene back to the wild type (prototrophic), the cell becomes disabled when the exogenous histidine is exhausted. For this reason, this assay is referred to as a reverse or back mutation assay. Since a single strain of a bacterium is capable of detecting only a specific type of genetic damage, several strains must be used to effectively screen for mutagenic potential. The S. typhimurium strains detect reversion from $\mathrm{His}^{-}$to $\mathrm{His}^{+}$at a single site in one of the 12 steps of histidine biosynthesis. Strains TA97 (hisD6610) and TA98 (hisD3052) are reverted from histidine auxotrophy to histidine prototrophy by frameshift mutagens, whereas TA100 (hisG46) is reverted by base substitution mutagens.

Strain TA102 (hisG428) possesses A-T base pairs at the site of the mutation unlike other $S$. typhimurium tester strains that possess G-C base pairs at the mutation sites. In addition, TA102 has been shown to be useful for detecting oxidative mutagens that are not detected by other tester strains (23). The hydroalcoholic extract was mutagenic to the TA98 strain (-S9), which can be clinically relevant since one of its popular uses is in cases of diarrhea or dysenteries (2). Thus, its oral administration can lead to an increase of gastrointestinal cancer, although its biotransformation determines the mutagenic activity loss, as shown using metabolic activation (+S9).

The $P$. reticulata extract also showed signs (a significant increase in revertants, but $\mathrm{MI}<2$ ) of mutagenicity to TA97a and TA102 (both -S9). To increase the sensitivity to mutagens, several additional mutations have been incorporated into the strains used in the standard assay, including in the $u v r B$ gene of S. typhimurium. Cells with this type of mutation are unable to repair damage

Table 1. Ames test (Salmonella typhimurium) for mutagenic activity (mean number of revertants/plate \pm SD) of the bacterial strains TA97a, TA98, TA100 and TA102 exposed to Plathymenia reticulata hydroalcoholic extract, at various concentrations, with (+) and without (-) metabolic activation (S9)

\begin{tabular}{c|c|c|c|c|c|c|c|c}
\hline \multicolumn{9}{c}{ Salmonella typhimurium strains } \\
\hline \multirow{2}{*}{$\begin{array}{c}\text { Treatment } \\
\text { mg/plate }\end{array}$} & - S9a & + S9b & - S9a & + S9b & - S9c & + S9b & - S9c & + S9d \\
\hline 0 & $122 \pm 21.5$ & $133 \pm 2.0$ & $22 \pm 4.0$ & $25 \pm 3.6$ & $127 \pm 1.5$ & $147 \pm 9.5$ & $190 \pm 18.9$ & $272 \pm 21.5$ \\
\hline \multirow{2}{*}{2.84} & $171 \pm 25.2$ & $127 \pm 8.9$ & $19 \pm 1.5$ & $19 \pm 0.6$ & $172 \pm 30.1$ & $118 \pm 6.2$ & $255 \pm 8.1^{* *}$ & $257 \pm 9.2$ \\
& $(1.4)$ & $(1.0)$ & $(0.8)$ & $(0.7)$ & $(1.3)$ & $(0.8)$ & $(1.5)$ & $(0.9)$ \\
\hline \multirow{2}{*}{5.68} & $183 \pm 10.0^{*}$ & $137 \pm 5.9$ & $31 \pm 6.1$ & $24 \pm 0.6$ & $134 \pm 19.0$ & $118 \pm 8.0$ & $289 \pm 25.5^{* *}$ & $243 \pm 21.4$ \\
& $(1.5)$ & $(1.0)$ & $(1.4)$ & $(0.9)$ & $(1.0)$ & $(0.8)$ & $(1.8)$ & $(0.8)$ \\
\hline \multirow{2}{*}{11.37} & $203 \pm 15.3^{*}$ & $138 \pm 9.6$ & $31 \pm 11.1$ & $20 \pm 6.4$ & $153 \pm 23.7$ & $126 \pm 9.2$ & $220 \pm 20.6$ & $226 \pm 11.3$ \\
& $(1.7)$ & $(1.0)$ & $(1.4)$ & $(0.8)$ & $(1.2)$ & $(0.9)$ & $(1.2)$ & $(0.8)$ \\
\hline \multirow{2}{*}{17.06} & $210 \pm 15.9^{*}$ & $146 \pm 8.0$ & $44 \pm 11.2^{*}$ & $25 \pm 6.0$ & $171 \pm 17.2$ & $128 \pm 5.7$ & $208 \pm 9.2$ & $221 \pm 22.9$ \\
& $(1.7)$ & $(1.1)$ & $(2.0)$ & $(1.0)$ & $(1.3)$ & $(0.9)$ & $(1.2)$ & $(0.8)$ \\
\hline \multirow{2}{*}{19.90} & $223 \pm 10.7^{* *}$ & $126 \pm 8.0$ & $54 \pm 10.9^{*}$ & $22 \pm 0.8$ & $173 \pm 77.4$ & $125 \pm 4.5$ & $233 \pm 21.1$ & $192 \pm 13.3$ \\
& $(1.8)$ & $(0.9)$ & $(2.4)$ & $(0.8)$ & $(1.3)$ & $(0.9)$ & $(1.3)$ & $(0.7)$ \\
\hline \multirow{2}{*}{ Control + } & $1251 \pm 44.2$ & $1258 \pm$ & $1885 \pm$ & $733 \pm$ & $1157 \pm$ & $1243 \pm 122$ & $886 \pm 122.6$ & $854 \pm 59.9$ \\
\hline
\end{tabular}

0: negative control (DMSO, $100 \mu \mathrm{L} /$ plate); +: positive control. a NPD (4-nitro-o-phenylenediamine - $10.0 \mu \mathrm{g} /$ plate); b 2-anthramine (1.25 $\mu \mathrm{g} /$ plate); c sodium azide ( $1.25 \mu \mathrm{g} /$ plate); $\mathrm{d}$ mitomycin ( $0.5 \mu \mathrm{g} / \mathrm{plate})$.

The values in parenthesis represent the mutagenic index $\left[\mathrm{MI}\right.$, red color, ${ }^{*} \mathrm{p}<0.05$ (ANOVA)] or signs of mutagenicty [green color, ${ }^{* *} \mathrm{p}<0.05$ (ANOVA)]. 
induced by UV light or other types of mutagens. The $u v r \mathrm{~B}$ mutation has not been introduced in TA102 (23). Although the mutagenic index of $P$. reticulate extract for TA102 was not expressive, the result shows sensitivity to oxidative compounds present in the extract and to UV light. The results obtained using TA100 showed no mutagenic activity of $P$. reticulata extract, signifying a certain inability to cause base substitution (either in $-S 9$, as in + S9).

The micronucleus test in $\mathrm{CHO}-\mathrm{K} 1$ cells is able to detect chromosome fragments or lagging intact chromosomes in the cytoplasm of cells that have undergone division (24). The study of DNA damage at the chromosome level is an essential part of genetic toxicology because chromosomal mutation is an important event in carcinogenesis. The micronucleus assay has emerged as a new method for assessing and for routine screening of agents that damage chromosomes $(25,26)$. The micronucleus counts were obtained for all cells (mononucleate, binucleate, multinucleate cells), but only the binucleate cells were used in the Poisson model (14).

Figure 1 indicates that the RI percentages were higher than $77 \%$ for the $-S 9$ samples and were above $90 \%$ for the $+\mathrm{S} 9$ samples. The RI percentages for the $-\mathrm{S} 9$ samples corresponded to $94.1 \%$ at $0.5 \mu \mathrm{g} / \mathrm{mL}, 96.9 \%$ at $1.6 \mu \mathrm{g} / \mathrm{mL}$ and $97.7 \%$ at $5 \mu \mathrm{g} / \mathrm{mL}$ of the extract. The positive control percentages were $85.2 \%$ for mitomycin $\mathrm{C}$ and $77.5 \%$ for colchicine. The RI percentages obtained for the $+\mathrm{S} 9$ samples were $91.2 \%$ at 0.5 $\mu \mathrm{g} / \mathrm{mL}, 92.5 \%$ at $1.6 \mu \mathrm{g} / \mathrm{mL}$ and $91.4 \%$ at $5 \mu \mathrm{g} / \mathrm{mL}$ of the extract.

The percentages calculated for benzopirene and cyclophosphamide were $93.4 \%$ and $100.8 \%$, respectively. According to the OECD-487 procedure (13), the highest concentration should result in around $50 \pm 5 \%$ cytotoxicity. Higher levels may induce chromosome damage as a secondary effect of cytotoxicity. The highest cytotoxicity percentage was $22.5 \%$ and corresponded to colchicine (Figure 1). Based on this information, the performed experiments provided reliable results. The concentrations of test substance and positive controls were adequate for the samples and were chosen using specific guidelines.

The CBPI indicates the average number of cell divisions per cell during the period of exposure to cytochalasin B and may be used to estimate cell proliferation (13). This method is based on the frequent induction of cell cycle arrest, which is reflected by a decreased ratio of binucleate to mononucleate cells when using cytochalasin B. In this method, the level 1 (all cells are

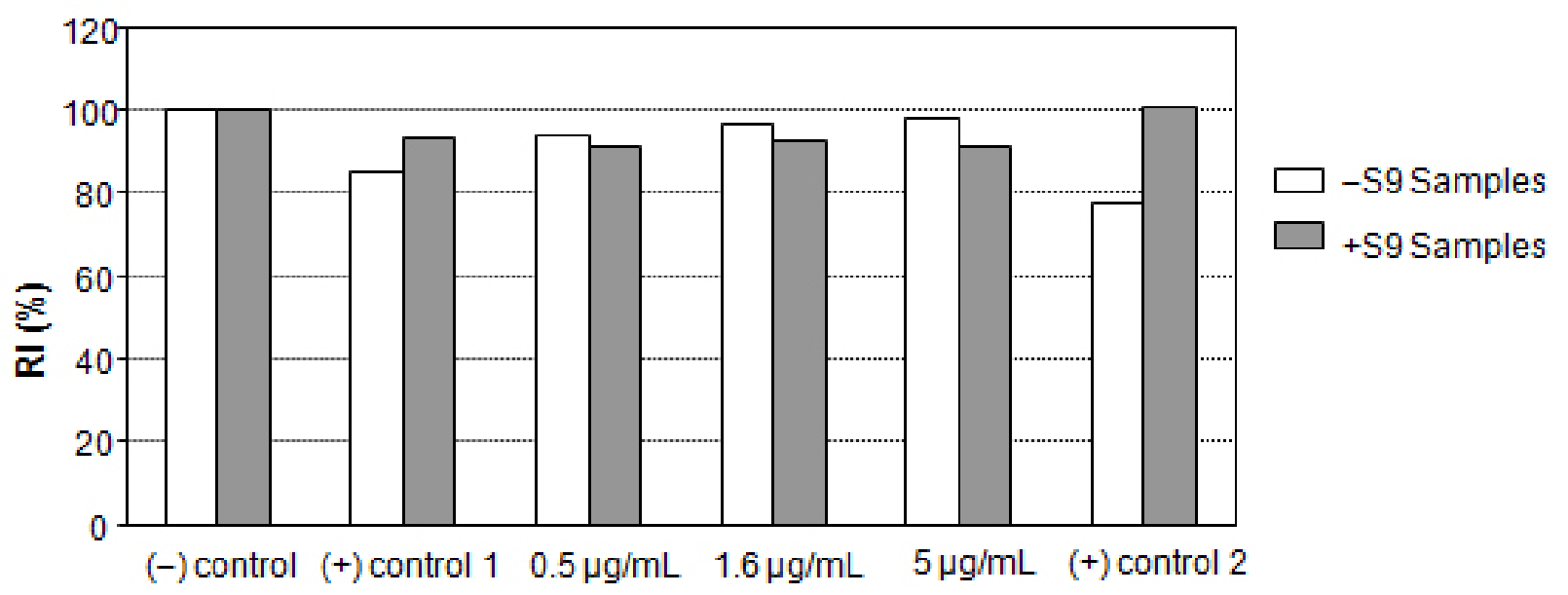

Samples

Figure 1. Micronucleus test (CHO-K1 line) and replication Index ( $\mathrm{Rl}$, mean expressed as percentage). Cells were treated with the extract in the presence (+) and absence (-) of metabolic activation (S9). The (-) control corresponds to the culture medium; (+) control 1 corresponds to benzo(a)pyrene (in experiments with S9) and mitomycin C (in experiments without S9); (+) control 2 is related to colchicine in the absence of S9 and to cyclophosphamide in the $\mathrm{S} 9$ treated cells. $\mathrm{CHO}$ : Chinese hamster ovary. 
mononucleate) of CBPI is equivalent to $100 \%$ cytostasis $(13,27)$. Our results showed that the sample concentrations were not cytotoxic.

According to theoretical considerations and published data, most aneugens and clastogens are detectable during a short treatment period of 3 to 6 hours in the presence $(+)$ or absence $(-)$ of S9, followed by removal of the tested substance and a recovery period of 1.5 to 2.0 cell cycles $(28$, 29). In the $+S 9$ assay, the cultures were incubated during a four-hour exposure period. After the treatment period, the cultures were returned to the incubator for an additional 20 hours. This time corresponds to approximately 1.5 cell cycles, since $\mathrm{CHO}-\mathrm{K} 1$ cells have an average doubling time of approximately 14 hours.

Exogenous metabolizing systems are required when cells with inadequate endogenous metabolic capacity are involved in in vitro experiments. The most common system used is a cofactorsupplemented post-mitochondrial fraction prepared from the livers of rodents that were treated with enzyme-inducing agents (13). For the in vitro micronucleus test, Aroclor-induced rat liver S9 homogenate was adopted as an exogenous activation system. According to Figure 2 , the exogenous metabolism system increased the number of viable cells when compared to the -S9 samples $(\mathrm{p}<0.05)$.

The mutagenic effect of $P$. reticulata was evaluated by the micronucleus test. According to Table 2, this percentage was lower than the $+\mathrm{S} 9$ negative control. For the $+\mathrm{S} 9$ and $-\mathrm{S} 9$ positive controls, the percentages were higher than the other samples. However, this was not observed for colchicine, which presented a lower micronucleus percentage than the test concentrations of $P$. reticulata extract.

The micronucleus frequency corresponds to the compound's mutagenic capacity and is based on the total count of micronuclei divided by the total number of binucleate cells. It was noted that the $P$. reticulata extract was less mutagenic when applied to $+S 9$ cells, a fact supported by a lower micronucleus frequency. As expected, there was a positive proportional increase in the micronucleus percentage between the $-S 9$ and $+S 9$ sample concentrations. It was also shown that colchicine did not provide an adequate positive control due to its low aneugenic potential, as observed through the low micronucleus occurrence.

Reifferscheid et al. (30) confirmed that the optional positive control colchicine induced micronuclei only in a very narrow concentration

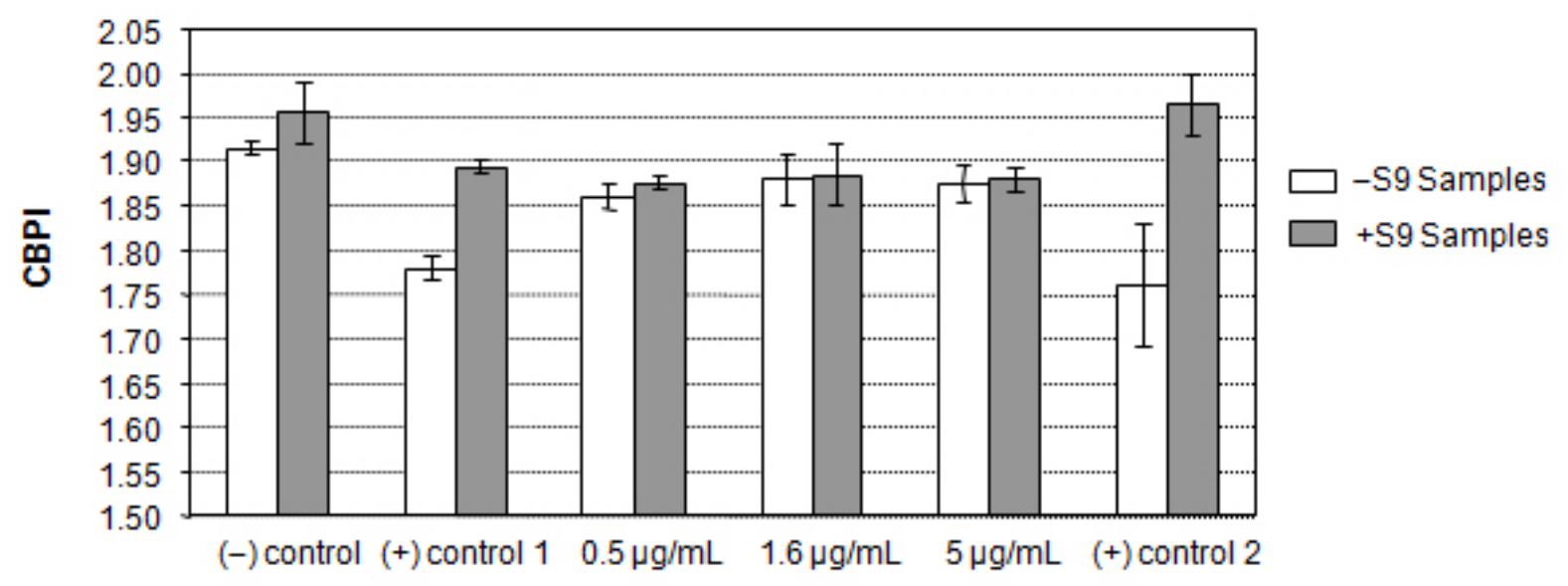

Samples

Figure 2. Micronucleus test (CHO-K1 line) and cytokinesis-block proliferation index (CBPI, average number of cell divisions per cell of the slides of the two wells \pm SD). Values obtained from the samples in the presence $(+)$ and absence $(-)$ of metabolic activation (S9). The (-) control corresponds to the culture medium of each sample; $(+)$ control 1 employed mitomycin $C$ and benzopyrene in - and + S9 samples for metabolic activation, respectively; $(+)$ control 2 is related to colchicine in the $-\mathrm{S} 9$ samples and to cyclophosphamide for the +S9 samples. CHO: Chinese hamster ovary. 
Table 2. Micronucleus test (CHO-K1 line) and cytokinesis-block proliferation index (CBPI, mean $\pm \mathrm{SD}$ ). Values and the related micronucleus frequency (MF, \%) of cells exposed to the Plathymenia reticulata Benth hydroalcoholic extract

\begin{tabular}{c|c|c|c|c}
\hline \multirow{2}{*}{ Agent } & \multicolumn{2}{|c}{ S9 } & \multicolumn{2}{c}{ S9 } \\
\cline { 2 - 5 } & CBPI (\%) & MF (\%) & CBPI (\%) & MF (\%) \\
\hline Control & $1.92 \pm 0.007$ & $1.36 \pm 0.27$ & $1.96 \pm 0.035$ & $2.86 \pm 0.34$ \\
\hline Pr at $0.5 \mu \mathrm{g} / \mathrm{mL}$ & $1.86 \pm 0.014$ & $4.05^{*} \pm 0.21$ & $1.88 \pm 0.007$ & $2.25 \pm 0.35$ \\
\hline Pr at $1.6 \mu \mathrm{g} / \mathrm{mL}$ & $1.88 \pm 0.028$ & $4.10^{*} \pm 0.85$ & $1.89 \pm 0.035$ & $2.30 \pm 0.42$ \\
\hline Pr at $5 \mu \mathrm{g} / \mathrm{mL}$ & $1.88 \pm 0.021$ & $4.75^{*} \pm 0.64$ & $1.88 \pm 0.014$ & $3.40 \pm 0.99$ \\
\hline Colchicine $0.08 \mu \mathrm{g} / \mathrm{mL}$ & $1.76 \pm 0.071$ & $3.59^{*} \pm 0.27$ & - & - \\
\hline Mitomycin C $0.5 \mu \mathrm{g} / \mathrm{mL}$ & $1.78 \pm 0.014$ & $6.05^{*} \pm 0.92$ & - & - \\
\hline Cyclophosphamide $5 \mu \mathrm{g} / \mathrm{mL}$ & - & - & $1.97 \pm 0.035$ & $3.79^{*} \pm 0.99$ \\
\hline Benzopyrene $3 \mu \mathrm{g} / \mathrm{mL}$ & - & - & $1.90 \pm 0.007$ & $5.74^{*} \pm 0.90$ \\
\hline
\end{tabular}

${ }^{*} \mathrm{p}<0.05$ (ANOVA); CHO: Chinese hamster ovary.

range between 0.01 and $0.015 \mu \mathrm{g} / \mathrm{mL}$. Higher concentrations of the aneugenic substance led to polyploid cells and, eventually, to cell death. Both conditions are unfavorable for the test evaluation, which is one reason for not considering this substance a standard positive control in the ISO draft.

The micronucleus frequency was about 2.9 higher for the $-\mathrm{S} 9$ samples in relation to the negative control, even though the retained percentage was lower than the positive controls. $P$. reticulata Benth hydroalcoholic extract did not present a mutagenic effect potential at concentrations of $0.5,1.6$ and $5 \mu \mathrm{g} / \mathrm{mL}$, mainly when the test was performed with the S9 metabolic activation system by both the Ames and micronucleus tests.

Results that express mutagenic activity may suggest that a specific agent is not safe for medicinal use. The positive mutagenicity property may exclude a plant from any further trial of preclinical tests, a crucial step in the development of new agents with clinical relevance $(31,32)$. Therefore, careful observation of cause and effect, followed by a coordinated approach to identify the responsible entities, would be extremely fruitful in discovering new therapeutic roles for the phytochemical constituents of $P$. reticulata, for example, as antitumoral agents.

$P$. reticulata extract - in spite of its previously demonstrated anti-inflammatory, antimicrobial and antiophidian effects- can also alter genetic properties, as shown by the Salmonella microsome and micronucleus tests, both of which are $-S 9(3,4,8)$. The antiophidian ability of $P$. reticulata extract was attributed to the presence of tannins, which act by precipitating venom proteins, also reproduced by commercial tannic acid. Both tannins and tannic acid significantly inhibit not only the impairment of muscle strength induced by Crotalus durissus terrificus and Bothrops jararacussu venoms, but also the lethality of cobra (Naja kaouthia) venom $(8,33)$. This protein-precipitating property of $P$. reticulata extract could limit its clinical use as a topical application - mainly against the local manifestation in cases of Bothrops snakebites due to high myotoxic action, but strategies for producing a hemoperfuser containing tannic acid and/or plant tannins as adsorbent could be considered for treating severe snake envenomation. Likewise, taken together, these results also indicate a probable new antitumoral property, which must be investigated in additional studies using isolated bioactive compounds, given that it is easier to ensure safety in the action of a single molecule rather than a mixture of compounds.

\section{ACKNOWLEDGEMENTS}

We would like to thank The National Council for Scientific and Technological Development (CNPq) and The State of São Paulo Research Foundation (FAPESP) for financial support, the 
University of Sorocaba for the infrastructure and Natália Mencacci Esteves-Pedro and Virginia Sbrugnera Nazato for their kind contribution to this study.

\section{COPYRIGHT}

(c) CEVAP 2011

\section{SUBMISSION STATUS}

Received: January 12, 2011.

Accepted: April 4, 2011.

Abstract published online: April 6, 2011.

Full paper published online: May 31, 2011.

\section{CONFLICTS OF INTEREST}

There is no conflict.

\section{FINANCIAL SOURCE}

CNPq and FAPESP provided the financial grants.

\section{ETHICS COMMITTEE APPROVAL}

The present study was approved by the Ethics Committee of Vale do Paraíba University (UNIVAP) under the protocol number A22/ CEP/2008.

\section{CORRESPONDENCE TO}

PATRICIA SANTOS LOPES, Instituto de Ciências Ambientais, Químicas e Farmacêuticas, UNIFESP, Rua Prof. Artur Riedel, 275, Diadema, SP, 09972-270, Brasil. Phone: +55 1133193308. Fax: +55 11 33196428. Email: patricia.lopes@ unifesp.br.

\section{REFERENCES}

1. Lacerda DR, Lemos Filho JP, Acedo MDP, Lovato MB. Molecular differentiation of two vicariant neotropical tree species, Plathymenia foliolosa and $P$. reticulata (Mimosoidae), inferred using RAPD markers. Plant Syst Evol. 2002;235(1-4):67-77.

2. Pott A, Pott VJ, Bueno Sobrinho AA. Plantas úteis à sobrevivência no Pantanal. IV Simpósio sobre Recursos Naturais e Sócio-econômicos do Pantanal [Internet]. Corumbá: BR; [updated Mar 11; cited 2004 Novemb 23]. Available from: www.cpap.embrapa.br/ agencia/simpan/sumario/.../ArnildoPott.PDF.

3. Pott A, Pott VJ. Plathymenia reticulata, LeguminosaeMimosoideae. In: Brazilian Agricultural Research Corporation, editor. Plants of Pantanal. Corumbá: EMBRAPA-CPAP; 1994. 320 p.

4. Fernandes TT, Santos AT, Pimenta FC. Atividade antimicrobiana das plantas Plathymenia reticulata, Hymenaea courbaril e Guazuma ulmifolia. Rev Patol Trop. 2005;34(2):113-22.
5. Leal RS, Lima MAS, Silveira ER. Cassane diterpenes from Plathymenia reticulata. J Braz Chem Soc. 2003;14(1):120-5.

6. King TJ, Rodrigo S. Plathyterpol, a diterpene from Plathymenia reticulata. Chem Commun (London). 1967;12:575a-575a.

7. Matos FJA, Craveiro AA, Maurera MAMA de. Furan diterpenes of the Plathymenia genus. J Nat Prod. 1984;47(4):581-4.

8. Melo RS, Farrapo NM, Rocha-Junior DS, Silva MG, Cogo JC, Dal Belo CA, et al. Antiophidian mechanisms of medicinal plants. In: Keller RB, editor. Flavonoids: byosynthesis, biological effects and dietary sources. New York: Nova Science Publishers; 2009. p. 249-62.

9. Maron DM, Ames BN. Revised methods for the Salmonella mutagenicity test. Mutat Res. 1983;113(34):173-215.

10. Bernstein L, Kaldor J, McCann J, Pike MC. An empirical approach to the statistical analysis of mutagenesis data from the Salmonella test. Mutat Res. 1982;97(4):267-81.

11. Varella SD, Pozetti GL, Vilegas W, Varanda EA. Mutagenic activity of sweepings and pigments from a household-wax factory assayed with Salmonella typhimurium. Food Chem Toxicol. 2004;42(12):202935.

12. Rodas AC, Maizato MJ, Leirner AA, Pitombo RN, Polakiewicz B, Beppu MM, et al. Cytotoxicity and genotoxicity of bovine pericardium preserved in glycerol. Artif Organs 2008;32(4):272-6.

13. OECD. Guideline for the testing of chemicals, draft proposal for a new Guideline $\mathrm{n}^{\circ} 487$, in vitro mammalian cell micronucleus test (MNvit) [Internet]. Paris: FR. Organization for Economic Co-Operation and Development. [updated 2011 Jan 08; cited 2007 Dec 13]. Available from: http://www.oecd.org/ dataoecd/38/58/39780112.doc.

14. Margolin BH, Resnick MA, Rimpo JY, Archer P, Galloway SM, Bloom AD, et al. Statistical analyses for in vitro cytogenetic assays using Chinese hamster ovary cells. Environ Mutagen. 1986;8(2):183-204.

15. Barbosa-Filho JM, Vasconcelos TH, Alencar AA, Batista LM, Oliveira RA, Guedes DN, et al. Plants and their active constituents from South, Central, and North America with hypoglycemic activity. Rev Bras Farmacogn. 2005;15(4):392-413.

16. Brandão MG, Cosenza GP, Moreira RA, Monte-Mor RL. Medicinal plants and other botanical products from the Brazilian Official Pharmacopoeia. Rev Bras Farmacogn. 2006;16(3):408-20.

17. Lima MR, Ximenes CP, Luna JS, Sant'Ana AE. The antibiotic activity of some Brazilian medicinal plants. Rev Bras Farmacogn. 2006;16(3):300-6.

18. Aquino FG, Walter BM, Ribeiro JF. Espécies vegetais de uso múltiplo em reservas legais de Cerrado - Balsas, MA. Rev Bras Biociênc. 2007;5(1):147-9.

19. Caramori SS, Lima CS, Fernandes KF. Biochemical characterization of selected plant species from Brazilian Savannas. Braz Arch Biol Technol. 2004;47(2):253-9.

20. Fennell CW, Lindsey KL, McGaw LJ, Sparg SG, Stafford GI, Elgorashi EE, et al. Assessing African medicinal 
plants for efficacy and safety: pharmacological screening and toxicology. J Ethnopharmacol. 2004:94(2-3): 205-17.

21. Ruggiero P, Tombola F, Rossi G, Pancotto L, Lauretti L, Del Giudice G, et al. Polyphenols reduce gastritis induced by Helicobacter pylori infection or VacA toxin administration in mice. Antimicrob Agents Chemother. 2006;50(7):2550-2.

22. $\mathrm{Hu} \mathrm{H}$, Qin Y-M. Grape seed proanthocyanidin extract induced mitochondria-associated apoptosis in human acute myeloid leukaemia 14.3D10 cells. Chin Med J (Engl). 2006;119(5):417-21.

23. Putman DL, Gudi R, Wagner III VO, San RHC, Jacobson-Kram D. Genetic toxicology. In: JacobsonKram D, Keller KA, editors. Toxicology testing handbook. Principles, Applications, and Data Interpretation. New York: Marcel Dekker, Inc; 2001.

24. Bryce SM, Bemis JC, Avlasevich SL, Dertinger SD. In vitro micronucleus assay scored by flow cytometry provides a comprehensive evaluation of cytogenetic damage and cytotoxicity. Mutat Res. 2007; 630(12):78-91.

25. Fenech $M$. The in vitro micronucleus technique. Mutat Res. 2000;455(1-2):81-95.

26. Ciaravino V, Suto MJ, Theiss JC. High capacity in vitro micronucleus assay for assessment of chromosome damage: results with quinolone/naphthyridone antibacterials. Mutat Res.1993;298(4):227-36.

27. Diaz D, Scott A, Carmichael P, Shi W, Costales C. Evaluation of an automated in vitro micronucleus assay in CHO-K1 cells. Mutat Res. 2007;630(1-2):113.
28. Lorge E, Thybaud V, Aardema MJ, Oliver J, Wakata A, Lorenzon G, et al. SFTG international collaborative study on in vitro micronucleus test I. General conditions and overall conclusions of the study. Mutat Res. 2006;607(1):13-36.

29. Fenech M, Morley AA. Cytokinesis-block micronucleus method in human lymphocytes: effect of in vivo ageing and low dose $\mathrm{X}$-irradiation. Mutat Res. 1986; 161(2):193-8.

30. Reifferscheid G, Ziemann C, Fieblinger D, Dill F, Gminski R, Grummt HJ, et al. Measurement of genotoxicity in wastewater samples with the in vitro micronucleus test: results of a round-robin study in the context of standardisation according to ISO. Mutat Res. 2008;649(1-2):15-27.

31. Montanari-Junior I. Aspectos da produção comercial de plantas medicinais nativas [Internet]. Campinas: BR; [updated May 10; cited 2002 August 16]. Available from: www.cpqba.unicamp.br/plmed/artigos/ producao.htm.

32. Albertini S, Bös M, Gocke E, Kirchner S, Muster W, Wichmann J. Suppression of mutagenic activity of a series of $5 \mathrm{HT} 2 \mathrm{c}$ receptor agonists by the incorporation of a gem-dimethyl group: SAR using the Ames test and a DNA unwinding assay. Mutagenesis. 1998;13(4):397403.

33. Sia FY, Vejayan J, Jamuna A, Ambu S. Efficacy of tannins from Mimosa pudica and tannic acid in neutralizing cobra (Naja kaouthia) venom. J Venom Anim Toxins incl Trop Dis. 2011;17(1):42-8. 